\title{
INTEGRATION OF HISTORIC PLACES IN NEW URBAN DEVELOPMENT: A CASE STUDY OF PHITSANULOK, THAILAND
}

\author{
Nattika NAVAPAN ${ }^{1}$, Kornticha OONPRAI
}

DOI: $10.21163 / G T \_2019.141 .15$

\begin{abstract}
:
Historic area contributes to the memory of a city, creates urban identity, and forms the modern townscape. However, the historic areas worldwide are affected by the development processes led by globalized trend in architecture and planning. In urban development, particularly in Thailand, historical context is from time to time neglected or perceived as secondary. This study investigates the urban historic quarter in Phitsanulok, one of the main cities in the Northern part of Thailand, in order to make a clearer understanding about the roles of the places with historic value in new urban development. Following the concepts of cultural heritage and place-making, the study attempts to point out how the places with historic value should be taken into account to facilitate urban development, to build urban identity, and to promote better quality of city living. Its discussion is with reference to the questions that need to be considered before any development proposal-what is special in the community, how many quality places are located in the vicinity and how they are connected, and places that should be more meaningful.
\end{abstract}

Key-words: Cultural heritage, Place-making, Urban identity, Integration, Thailand.

\section{INTRODUCTION}

Historic area contributes to the memory of a city, creates urban identity, and forms the modern townscape (Bandarin \& Van Oers, 2012; International Council on Monuments and Sites, 2016). However, the historic fabric in townscape worldwide is affected by the development processes led by globalized trend in architecture and planning (see for examples: Zukin, 2009; Wang, 2012; Said et al., 2013; Gharib \& Salama, 2014; Kunc et al., 2014; Ptichnikova, 2016). In urban development, particularly in Thailand, historical context is from time to time neglected or perceived as secondary. In Phitsanulok's city core, historic places are located adjacent to central urban spaces, the development projects of which have been continued. This study attempts to point out how the places with historic value should be taken into account to facilitate urban development, to build urban identity, and to promote better quality of city living. It explores the historic fabric and its roles involving new urban development through the concepts of cultural heritage and placemaking.

Historic sites and material structures are usually a part of what are defined as cultural heritage. In this study, cultural heritage is understood as "the contemporary use of the past (Graham et al., 2000)." Definition of cultural heritage has shifted from antique material structures to an instrument for revitalizing urban areas and bringing in new businesses (Swensen, 2012; Vartic, 2015). Cultural heritage encompasses the remnants of a past, considered the potential to be a foundation for developing the place-specific character; therefore, relevant actors in city development take it as significant to include in new

\footnotetext{
${ }^{1}$ Naresuan University, Department of Architecture, Center of Excellence on Energy Technology and Environment, Phitsanulok, Thailand,nattikan@nu.ac.th;

${ }^{2}$ Naresuan University, Department of Architecture, Phitsanulok, Thailand, korntichao@gmail.com.
} 
development (Swensen, 2012). Use of heritage as an instrument in urban regeneration is a global phenomenon and mostly linked into development strategies for cultural industries and a process of place-making (Pendlebury \& Porfyriou, 2017).

The presence of historic factors is profoundly embedded in the notion of place, which, under an interdisciplinary light, underlines "the identification of places as they are expressed by their social, physical and psychological representations (Castello, 2006: p.59)." Contemporary studies of place embrace new conceptual issues including the concepts of place-making. Variously used in a field of urban design, 'place-making' is a term applied to creating attractive physical environment as a background of successful social space (Pendlebury \& Porfyriou, 2017). The term 'place-making' is often used as a synonymous or in association with 'place-branding' and 'place-marketing'. The latter two are the concepts used in city management to obtain competitive advantage (Bandarin \& Van Oers, 2012). A potential of applying place-making concept in the areas embedded with historic and cultural values obviously shows in an increasing use of place-making strategies in urban design policy for conservation areas. Through the place-making process, newly built constructions located in old historic areas can have benefit from people's accumulated perception about the site along time (Castello, 2006). This reflects the notion of place in the urban-architectural practice that place in planning entails not only physical but also social construction (Castello, 2006).

Public space is one of the key elements when applying the concept of place-making into the development practices (Project for Public Spaces, 2012; Silberberg et al., 2013). Project for Public Spaces/PPS, an American nonprofit organization and one of the prominent associations specializing in the promotion of places, emphasizes the influence of public space on the city as follows: public space, not private space, defines a character of a city; public spaces aid in building a sense of community, civic identity and culture and; public spaces promote social capital, economic growth and community revitalization (Project for Public Spaces, 2012). PPS argues that the greatest challenge at present is how to build inclusive, healthy, functional, and productive cities, and a key part leading to the answer is public space (Project for Public Spaces, 2012). Although the study of urban fabric is a complex issue, PPS suggests that the significant starting point in developing a concept for any public space agenda is to explore historical perspective, how the area functions, and what is truly meaningful to the local people (Project for Public Spaces, 2012).

In addition to a focus on material aspect, a great concern in urban development should also be paid to intangible culture to enhance local identity and avoid a production of copied places, a consequence of globalization (Porfyriou \& Sepe, 2016). The concepts of cultural heritage and place-making mentioned above displays the challenges in integration of historic places, embedding with intangible culture, into contemporary urban development, particularly that of public spaces, to promote the integrated city planning and design. Development policy and process vary widely according to national and local institutional frameworks and are formed within very different economic and political contexts. However, a close study of the selected city zone makes possible to analyze the relationship between new development and heritage issues as well as to explore the status assigned to the site's existing historic fabric (Swensen, 2012).

\section{METHODOLOGY}

Following the concept of cultural heritage and the place-making approach reviewed above, this study attempts to provide answers to the questions suggested by PPS, the 
questions that need to be considered before any development proposal - what is special in the community, how many quality places are located in the vicinity and how they are connected, and places that should be more meaningful. These questions highlight a necessity for an insight into any particular area prior to its development planning. As Doratli et al. (2004) also state, identifying what is valuable in a historic urban quarter and what qualities that should be enhanced is a primary stage of strategic planning approach, a comprehensive and integrated approach, to conservation of historic urban quarters.

Based on qualitative research method, this study follows the case-study approach and applies observation, document study, and critical evaluation as the research methods. The study mainly relies on data gathered from planning documents, local literature and research, field observation and photo documentation.

\section{THE STUDY}

Phitsanulok is a city located in Lower Northern Thailand and regarded as a main city in the region. It has a long history dated back to the $10^{\text {th }}$ century but its distinctive role as a strategic border town came into view from 1350 s on. Once served as the capital city for 25 years, Phitsanulok mainly played its role as a strategic town until the great shift in national administration in 1894 made it a circle called Monthon Phitsanulok, later developed to be a province in the present day. Phitsanulok today is the regional commercial and transportation hubs and developing towards the country's central hub of East-West Economic Corridor, initiated in order to promote development and integration of four Southeast Asian countries. Furthermore, because the city is planned as a point where the East-West Economic Corridor meets the North-South Economic Corridor, Phitsanulok's Indochina project has been included in the city's development plan as shown in the provincial vision "Phitsanulok: Indochina's service city".

The central area of Phitsanulok city today, where this study focuses on, is geographically a plain with the Nan River running through it. Like other countries in the Southeast Asian region, in which traditional human settlements were clustered along the waterways, Phitsanulok city was established along the waterfront areas. The city went through a significant shift in its physical development in 1957 when the great fire destroyed vast area of the city. After the great fire, the so-called modern planning was introduced into the city. This new development brought about the changes in settlement, regarding its location and architectural style. Although the settlement along the Nan River was not physically affected, the commercial cluster with new modern concrete buildings was developed around the railway station. The city center expanded and gradually moved from the river ports to other transportation hubs, namely railway station and bus station. It was clear that roads gained more importance to the city and inter-city transportation when the bridges were built across the river and people's daily transport was rarely seen in the river. Within this modern context, where roads has replaced the river for transportation, the commercial center has been moved inland, and the traditional floating houses have been removed from the river, urban life seems to be cut off from the river once lifeline of the city. However, the waterfront developments initiated later on by the local municipality brought back people to the river in a new way.

The development of the waterfront public park (Chom Nan Park) is divided into phases and covers the areas of both banks of the river (Fig. 1). The area in focus of this study (Fig. 2) includes the waterfront public space developed in the first phase on the east bank of the river in the year 1999 (Fig. 3), and the recently developed and undergoing Central Park

(Fig. 4). The Central Park is another important development added in the city landscape. It 
is planned to be a new public park that links to the existing waterfront public space (Chom Nan Park).

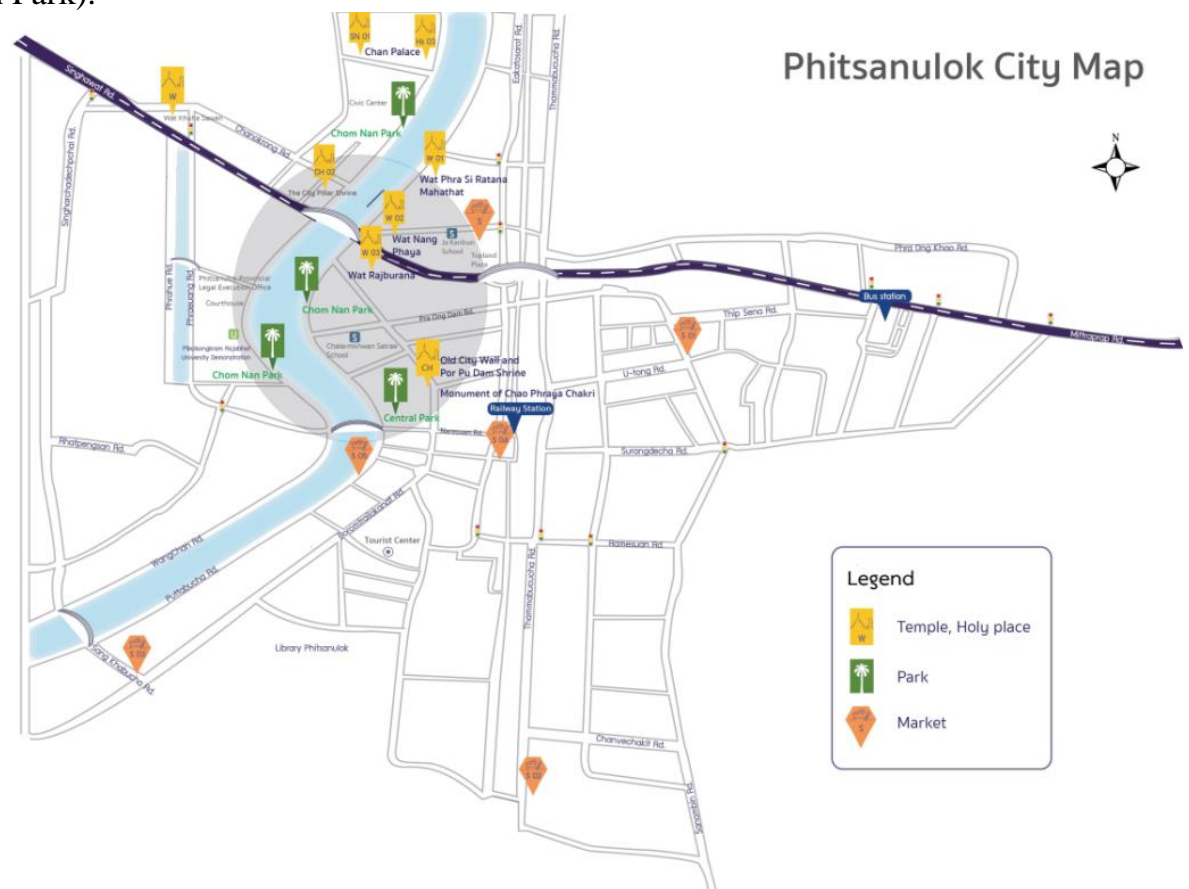

Fig. 1. A map of Phitsanulok's urban quarter (Source: authors).

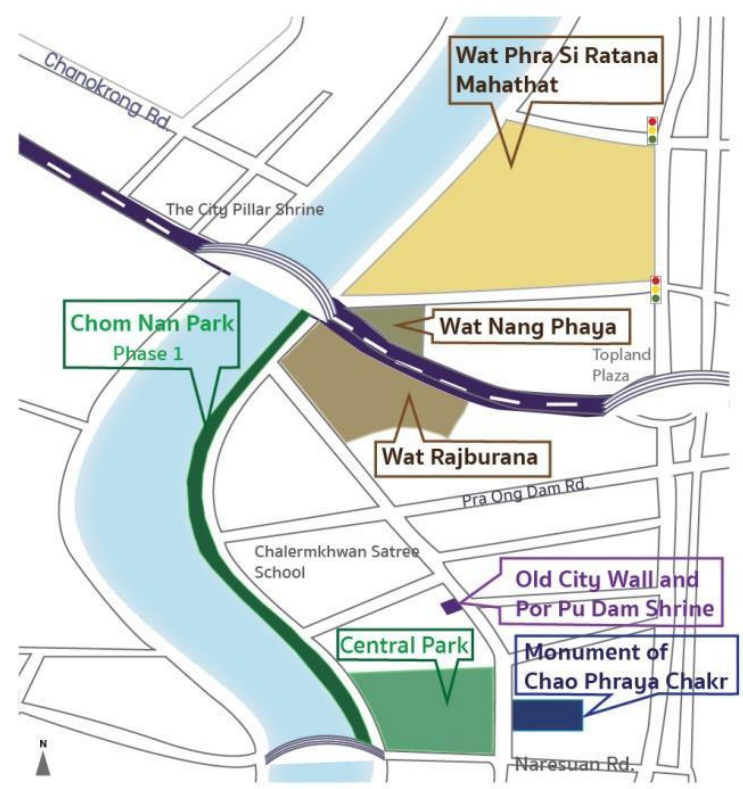

Fig. 2. A map showing the studied area. 

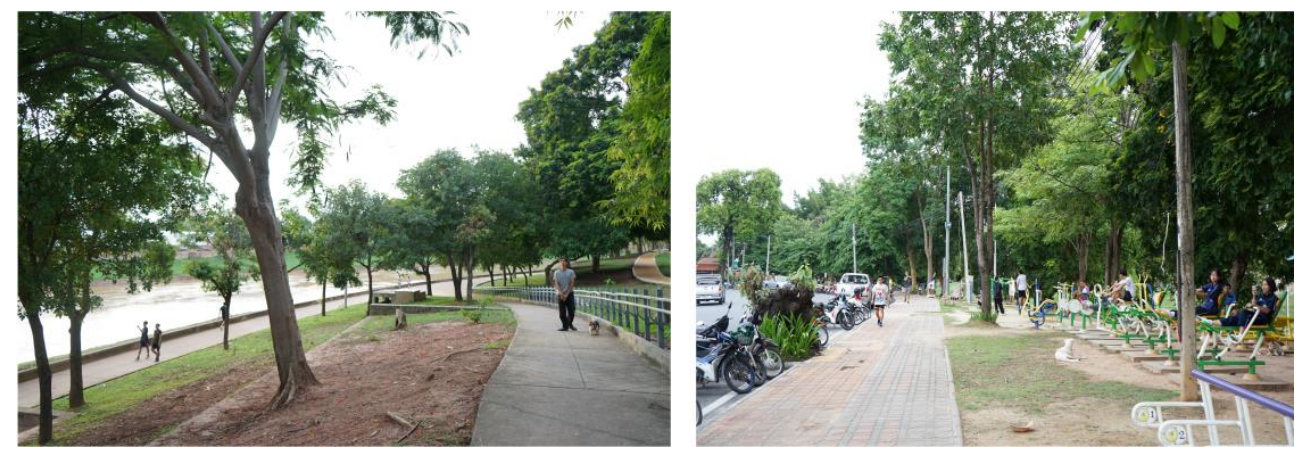

Fig. 3. Chom Nan Park (phase 1).

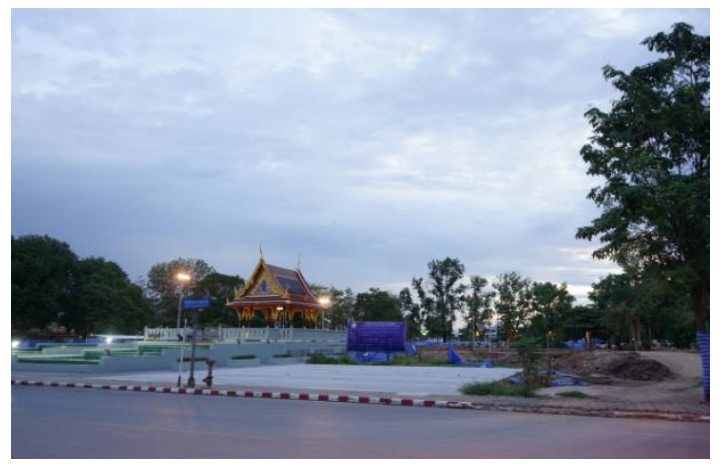

Fig. 4. Phitsanulok's Central Park (under construction).

Regarding historic places, Phitsanulok as a historic city is physically illustrated by the structural remains from its past. Its historic quarter is right at the heart of the city. Located in the studied area are three Buddhist temples, a royal monument, and the remains of the old city walls (Fig. 2). Although other several historic places are also in the vicinity, the studied area is selected because it encompasses the undergoing project of city development. A combination of old and new structural elements makes the study up to date and, therefore, its result could possibly be applied to future development plan to approach an extensive planning.

Phitsanulok Municipality's vision, "city of beautiful landscape and cheerful people”, is pronounced in the three-year development plan (2017-2019). According to the plan, the development policy directly points out the building and strengthening of city identity by employing its rich natural and social resources. The Municipality also mentions a promotion of local culture to strengthen urban identity and encourage tourism. Public spaces, including those located in the studied area, are a part of the Municipality's missions, which aim to improve infrastructure and people's quality of living. A review of the local municipality's vision and development plan demonstrates a concern about the urban identity, an awareness of natural and social (including historic) resources as valuable for identity building, and a promotion of urban public spaces. It helps ensure the significance of this study focusing on the integration of historic places in contemporary urban composition to strengthen the city identity and to enhance quality of urban living. 


\section{RESULTS AND DISCUSSIONS}

\subsection{A network of historic places and the city development}

Development projects have concerned heritage structures as single buildings or monuments rather than focused on local districts; therefore, many bordering structural elements, representing disseminators of historical contexts, have been lost (Swensen, 2012). Hence, the integration of dynamic local contexts should be more considered and the urban building heritage should be regarded as time-and-place specific resources to induce new activities and attractions (Swensen, 2012). The network of places connecting historic structures to their locales and other places is then needed to be proposed in development planning. Since place-making is one of pragmatic tools to develop a network of urban places scattered around the urban area (Castello, 2006), this study follows the place-making approach to examine a network of places in Phitsanulok's city quarter. As mentioned earlier, its investigation is guided by the questions - what is special in the community, how many quality places are located in the vicinity and how they are connected, and places that should be more meaningful.

Phitsanulok's history and collective memory apparently plays a key part in building the city's identity, for instance, an attempt to link with the past by naming the streets throughout the city with references to royal or legendary individuals in the history. Historic sites and structures, representing history of the city and at the same time surrounded by modern public spaces famous for local dwellers, also create a great combination to make a unique characteristic of Phitsanulok's urban quarter, and possibly the city as a whole. The presence of old and new structures situated in close proximity is, thus, a distinctive character of the area that could be enhanced.

As shown in the map (Fig. 2), a group of significant Buddhist temples all dated back to Sukhothai era (13 $3^{\text {th }}$ to $15^{\text {th }}$ centuries) are situated in the area: Wat Phra Si Ratana Mahathat, known by locals as Wat Yai and houses one of the country's most revered Buddha images; Wat Nang Phaya, famous for its amulet respected as one of the most sacred amulets in Thai history and; Wat Rajburana with its dominant historic buildings. Other historic structures in the area are the remains of the old city wall, now also a site of a shrine. With its historic value, a new monument of Chao Phraya Chakri (King Rama I) is built at the site near the remains of the old city wall in a remembrance of a historical event related to the SiameseBurmese war. These historic places and the city's new urban spaces, such as the Chom Nan Park, have formed urban context for contemporary living.

Although this combination is a familiar scene to local people, their daily activities show that these historic places are not well included to urban daily life but play main roles in tourism. However, since these historic places and modern public spaces are located (or planned to be located) in the vicinity, there are strong potentials to create more engagement between them. In terms of their connection, a main road and a local street make a harsh separation between the Buddhist temples and waterfront public spaces (Chom Nan Park) (Fig. 5), whilst another local street disconnects the heroic monument from the newly developed Central Park (Fig. 6). However, the street running pass Wat Rajburana, Chom Nan Park, and Central Park occasionally functions as a main venue for local events, including those related to cultural and religious affairs. Although it was included in building design, the linkage between the Central Park and the remains of the old city wall is not materialized because of an unintended situation. 

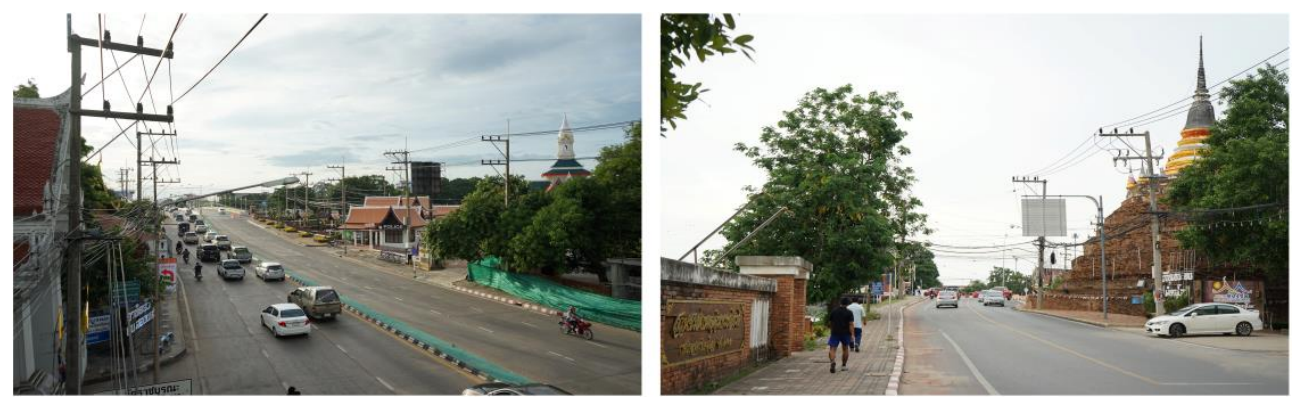

Fig. 5. A main road with Wat Rajburana on one side and Wat Phra Si Ratana Mahathat and Wat Nang Phaya on the other side (left) and a street in front of Wat Rajburana (right).

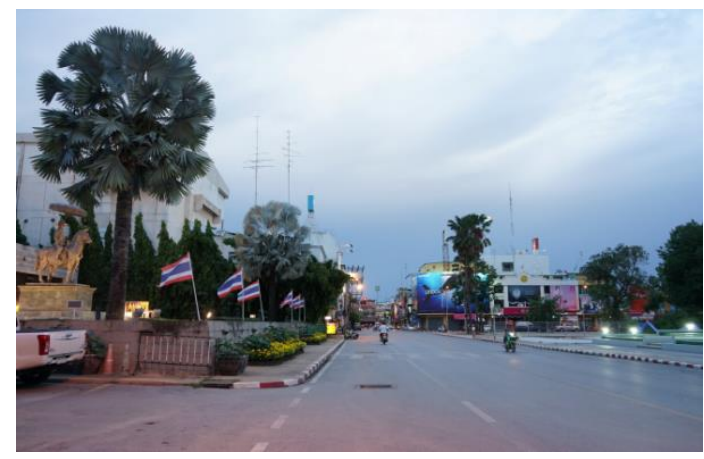

Fig. 6. A street in front of Chao Phraya Chakri Monument.

Apart from being a vital natural environment in the area, the Nan River in the past was a lifeline and a center of all activities. It, therefore, constructs to people's collective memory. With this quality, the river could be a key part to be considered in order to make a linkage between old and new. Once connected to the river, the Buddhist temples are now separated from the waterway, whilst the new public spaces are instead linked to the river and use it to serve their modern functions. Why cannot the river link to both new and historic structures and then serve both environmental and memorial functions? Modern developments bring the river into their uses, but why do not bring in the city memory as well? To consider the river as a beginning point, the connection between old and new may be created to serve both people's activities and memories.

\subsection{Integration of historic places in urban quarter}

According to the place-making approach, people's activities are one of the key factors to make successful place. A good network of activities creates a flow of people and establishes a lively neighborhood. These activities are not limited to those taking place in open spaces, but include the activities that occur in the buildings nearby. An integration of public sites into urban life cycles creates continuous use and, hence, enhances satisfaction of both local residents and tourists (Porfyriou \& Sepe, 2016). As for Phitsanulok's city quarter, the area consists of large public open spaces, public buildings, offices, shops, and historic buildings and sites. 
Accordingly, the area is full of various activities and serves people of all groups. However, the historic parts of the area seem to play a distinctive role in tourism and less involve in everyday urban life. As seen from the surroundings of the historic places, the separation from urban life is a consequence of the road and streets that run through and disconnect the historic sites from nearby urban spaces, as well as, the rigid boundaries of the historic places that create definite enclosures (Fig. 7).

Following the place-making concept, accessibility of pedestrians is one of the significant factors that help shape a good network of activities. Furthermore, "public spaces in and around historic monuments or historic parts of towns provide much needed opportunities to engage and interact with the city and its inhabitants; build a sense of community; and provide a space for exchange (International Council on Monuments and Sites, 2016)". Therefore, as in this studied area, the historic places possibly play better role in urban daily life if they are well connected with the dynamic urban spaces and if their boundaries are less rigid. This means the pedestrians can have more chances to get involve, on purpose or not, with the historic parts of the city.

More than a design of crosswalks, pedestrian spaces should be taken into account to make a link between the historic places and modern urban parks. Control of motor traffic should be introduced to put pedestrians on the first priority in space and allow them to safely and freely engage with all activities without any interruption.
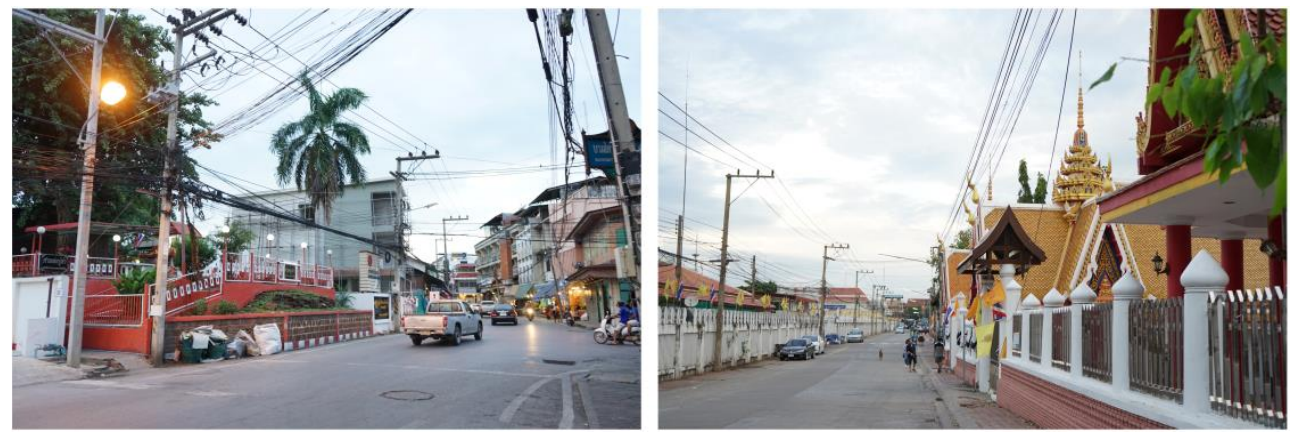

Fig. 7. Rigid boundaries of historic places.

The boundaries of the historic sites, e.g. walls and fences, could be redesigned to decrease the rigidness and welcome urban pedestrians. This network could enable a connection to the river, which then serve people both physically and psychologically people use spaces for modern requirements, whilst recognize their own past.

Accordingly, the river could play more roles in people's life and people could be better aware of its contribution to the city from the past up to the present. Even recent past can be recalled such as the disappearing floating houses, once densely settled in this part of the river and their large amount was as significant as they have been mentioned in the provincial motto. Effective integration of historic parts to the city could engage people to places and their past, enhance historic characteristic of the city, and bring back daily functions to historic places, not only for tourism but also education and recreation. 


\section{CONCLUSIONS}

Phitsanulok has long history and its nationally famous historic structures are located right at the heart of the city. These conditions reveal the high potentials for the city to strengthen its unique character by taking the historic places as valuable resources for city planning. By providing more roles to historic places and making their cultural values more obvious in the modern context, new urban development could make the locals more aware of and connect with their own past and that would lead to their pride in self and community, apart from the monetarily benefit from tourism.

Following the place-making approach, employed to guide the analysis in this study, the network of places in Phitsanulok's historic quarter could be developed by making spatial link between historic sites and the river and also by improving the link between the river and the public open spaces. It is to bring back the river to people's life and memory of the past. The historic places with less rigid boundaries and well-managed pedestrian spaces could complete the network and facilitate a vigorous flow of people.

In conclusion, the cities worldwide facing rapid global change could hardly escape the transformation. This study attempts to instigate the discussion of how cultural heritage possibly be integrated in modern city context. It illustrates that an integration of historic places in new urban development could make the places more meaningful and could enhance a network of urban spaces. It also suggests that modern development planning in Phitsanulok, a common case within Thai cultural context, should place a greater emphasis on the opportunities that the existing material structures with historic and cultural values are rich resources for strengthening the city image, as well as, improving the quality of living.

\section{REFERENCES}

Bandarin, F. \& Van Oers, R. (2012) The Historic Urban Landscape: Managing Heritage in an Urban Century, John Wiley \& Sons, West Sussex.

Castello L. (2006) City \& Time and Places: Bridging the Concept of Place to Urban Conservation Planning, City \& Time 2(1), 59-69.

Doratli, N., Hoskara, S., \& Fasli, M. (2004) An Analytical Methodology for Revitalization Strategies in Historic Urban Quarters: A Case Study of the Walled City of Nicosia, North Cyprus, Cities, 21(4), 329-348.

Gharib, R. \& Salama, A. (2014) Nature of Urban Interventions in Changing the Old Center of a Globalizing Doha. Frontiers of Architectural Research, 3(4), 468-476.

Graham, B., Ashworth, G. J., \& Tunbridge, J. E. (2002) A Geography of Heritage: Power, Culture and Economy, Arnold, London.

International Council on Monuments and Sites (ICOMOS) (2016) Cultural Heritage, the UN Sustainable Development Goals, and the New Urban Agenda. Concept Note. Available from: http://www.usicomos.org/wp-content/uploads/2016/05/Final-Concept-Note.pdf [Accessed March 2019].

Kunc, J., Navratil, J., Tonev, P., Frantal, B., Klusacek, P., Martinat, S., Havlicek, M. \& Cernik, J. (2014) Perception of Urban Renewal: Reflexions and Coherences of Socio-spatial Patterns (Brno, Czech Republic). Geographia Technica, 9(1), 66-77.

Pendlebury, J. \& Porfyriou, H. (2017) Heritage, Urban Regeneration and Place-Making, Journal of Urban Design, 22(4), 429-432.

Porfyriou, H. \& Sepe, M. (2016) Port Cities and Waterfront Developments: From the Re-actualization of History to a New City Image, In Porfyriou, H. \& Sepe, M. (2016) Waterfronts Revisited: European Ports in a Historic and Global Perspective, Routledge, New York. 
Project for Public Spaces, Inc. (2012) Placemaking and the Future of Cities. White Paper. Available from: https://www.pps.org/reference/placemaking-and-the-future-of-cities/ [Accessed July 2018].

Ptichnikova, G. (2016) New Century High Risers in the Core Areas of Historic Cities in Russia. Procedia Engineering, 165(2016), 1903-1910.

Said, S., Aksah, H. \& Ismail, E. (2013) Heritage Conservation and Regeneration of Historic Areas in Malaysia. Procedia - Social and Behavioral Sciences, 105, 418-428.

Silberberg, S., Lorah, K., Disbrow, R. \& Muessig, A. (2013) Places in the Making: How Placemaking Builds Places and Communities. White Paper, Massachusetts: Massachusetts Institute of Technology.

Swensen, G. (2012) Integration of Historic Fabric in New Urban Development-A Norwegian CaseStudy. Landscape and Urban Planning, 107(4), 380-388.

Vartic, L. (2015) Cartographic visual expression, a means of communication and exploration in architecture and art. Geographia Technica, 10 (1), 90-95.

Wang, J. (2012) Problems and Solutions in the Protection of Historical Urban Areas. Frontiers of Architectural Research, 1(1), 40-43.

Zukin, S. (2009) Destination Culture: How Globalization Makes All Cities Look the Same. Inaugural Working Paper Series, New York: Center for Urban and Global Studies at Trinity College. 